Saving the Mother of Brazil | 60

MARIA PAULA ANDRADE ${ }^{1}$

\title{
Saving the Mother of Brazil: Indigenous Peoples and Active Citizenship amid COVID-19²
}

The fight of indigenous peoples in Brazil for adequate health treatments and protection during the COVID-19 pandemic represents a critical pushback on the Brazilian state's attempts to limit social participation in political decisions (Lima, 2019; $A P I B, 2020 \mathrm{~b})$. The national and international support that the Brazilian indigenous population has sought to have their rights met, while the country hit the third position among the highest COVID-19 cases in the world in September 2020, is an evidence of their active pursuit toward direct participation in public policy $(A P I B, 2020 \mathrm{~b})$. In creating spaces of mobilization to demand healthcare from the government and strategies for the protection of their communities, indigenous peoples demonstrate their deep awareness over their constitutional, human, and citizenship rights (APIB, 2020b; APOINME, 2020). During the pandemic, they have utilized this knowledge to advance their demands for the upholding of their rights to differential treatment, to expose the government in its shortcomings and violations of its responsibilities, and to pressure the Brazilian state into holding accountability of its (in)actions (APIB, 2020b, 2020d). This paper examines the exercise of active citizenship among indigenous peoples in Brazil as they developed strategies to cope with the threats of COVID-19 and with their struggles with the Brazilian government. It seeks to understand how their commitment to active citizenship contributes to the strengthening of democratic

\footnotetext{
${ }^{1}$ Maria Paula Andrade is a fifth-year graduate candidate in the History department, at Vanderbilt University. She holds a B.A. in Language Teaching from the Federal University of Pernambuco in Brazil, and an M.A. in Latin American Studies from the University of North Carolina at Charlotte.

2 This article was originally published in http:/www.alternautas.net/blog/2021/5/19/saving-themother-of-brazil-indigenous-peoples-and-active-citizenship-amid-covid-19
} 
values in Brazil as they utilize social and political spaces to shape state decisions and guarantee their self-determination.

Indigenous challenges for access to adequate health assistance during the pandemic result from former president Michel Temer and current president Jair Bolsonaro's political maneuvers to disempower participatory democracy (Lima, 2019). Participatory democracy relates to citizen participation in policy-making through policy councils, conferences or public hearings, for example, which have begun to suffer dismantling by the federal government( Lima, 2019). The importance of participatory democracy lies in the opportunity it provides for underrepresented groups to voice their concerns, and improve the quality of state decisions. It relates to the relevance of citizenship, contestation and social participation as markers of democracy and of more accountable governments (Lima, 2019). In this case, the actions of indigenous organizations in Brazil to defend their health rights have been intrinsically connected with the markers of participatory democracy: from lawsuits to social mobilization, from strategies of combat and control of COVID-19 in their communities to reporting of state violations, they have shaped the maintenance and strengthening of democratic values (Ministério Público Federal, 2020; Landau, 2020). Ultimately, indigenous peoples seek to defend "the mother of Brazil [who] is indigenous, although the country is prouder of its European father who treats it like a bastard child (...)(Xapuri Socioambiental, 2020)."

This article draws on the literature of public health in Latin America and Brazil to examine the role of health in the indigenous' pursuit of their acquired rights, and their attempts to shape the terms of, and decisions in official health assistance amid COVID-19 (Chalhoub, 1996; Cueto and Palmer, 2015; Sowell, 2015; Westphal et al., 2007; Hochman, 2011; Gibson, 2019). Through the analysis of newspaper articles, reports from indigenous organizations, legislative decisions, constitutional and health rights, this paper seeks to answer the following question: how do the strategies indigenous peoples have developed to pressure the Brazilian government into fulfilling its constitutional responsibilities during the COVID-19 pandemic demonstrate their exercise of active citizenship and contribution to the strengthening of democracy? I argue that they do so by demanding both the federal government to hold accountability for its omission 
Saving the Mother of Brazil | 62

and detrimental attitudes during this health crisis while also demanding direct participation in state decisions regarding indigenous health.

\section{Methodology}

The use of the term citizenship requires a closer examination. Citizenship in Latin America has been at the core of indigenous mobilization, especially when it has created exclusion by restricting national membership to a particular national group (Yashar, 2005). The attribution of citizenship in the region is often granted by the state through one's birth within territorial boundaries, tied to ideas of civic inclusion, equality, fraternity and freedom, while entailing rights and responsibilities between citizenry and the state (Yashar, 2005). Yet, indigenous populations have challenged statist terms of inclusion concerning their impact on indigenous self-determination, namely, their political autonomy over their natural resources, territories and cultures as a basic human right (Yashar, 2005; Bodley, 2014).

To understand how Brazilian indigenous peoples have done so during the COVID-19 pandemic, I make use of the term "active citizenship" to refer to forms of civic engagement which go beyond statist citizenship, meaning, citizenship that sees the state as the only source of legitimate citizenship rights (Miraftab and Wills, 2005; Souza and Souza, 2020). Indeed, ethnic movements in Latin America, Asia, Africa and Southern Europe during the early 2000s contested prevailing notions of nation-states as legitimate sources of definition and extension of democratic citizenship and responsibilities (Yashar, 2005). Active citizenship thus concerns the popular pursuit of civil, social, political, and economic rights, which can take place outside official spaces (such as courtrooms) to be performed, as indigenous peoples have shown, in the streets, on the internet, in their villages, and abroad (Miraftab and Wills, 2005; APIB, 2020a, 2020b) ${ }^{3}$. Indigenous civic involvement thereby does not mean indigenous acceptance of nation-state paradigms of belonging, but the very tension of rights to selfdetermination that indigenous populations never relinquished despite how state

\footnotetext{
${ }^{3}$ Actors in this process also create their own spaces for communication to attract constituents to their cause. For more, see Miraftab and Wills (2005).
} 
laws have framed their national presence (Million, 2013; Holder and Corntassel, $2002)^{4}$.

Indigenous pursuit of resources to combat and control of COVID-19 among their peoples are predicated on their right for differential treatment under the Brazilian state (Hale, 2004; Sartori Junior and Leivas, 2017) ${ }^{5}$. Differential treatment was a victory of indigenous movements during the elaboration of the 1988 constitution defined in the article 231 of the constitution:

To indigenous peoples it is acknowledged their social organization, habits, languages, beliefs and traditions, as well as their original rights over the lands they have traditionally occupied. It is under the responsibility of the Union to demarcate them, protect them and make their possessions respected (Senado Federal, 1988).

Article 231 also contributed to the development of a subsystem of indigenous health under the national public health system, which stipulated the following:

It is mandatory to consider the local realities and the specificities of indigenous cultures and the approach to be adopted toward the care of indigenous health through a differential and global model, contemplating aspects of health assistance, sanitation, nutrition, housing, the environment, land demarcation, sanitary education and institutional integration (Presidência da República: Casa Civil, 1999).

\footnotetext{
${ }^{4}$ Their challenges to liberal paradigms of belonging also include how their view of collective rights for claims making has challenged liberal understandings of individual rights found in the "Draft Universal Declaration on the Rights of Indigenous Peoples" in the 1980s. For more, see Cindy L. Holder and Jeff J. Corntassel (2002).

${ }^{5}$ The acquisition of indigenous rights at the global and national levels reflected transformations in human rights and international law since the $1980 \mathrm{~s}$ that came to incorporate the right to differentiation into their norms. Indigenous peoples played a key role in these changes, particularly as they began to advocate for multiculturalism. This term however has become controversial in the literature because scholars have claimed the idea of multiculturalism as an emancipatory and counter-hegemonic project has been appropriated by neoliberalism, which has stipulated the benefits indigenous peoples can have access to and those they cannot. For more, see Charles R. Hale (2004) and Dailor Sartori Junior and Paulo Gilberto Cogo Leivas (2017).
} 
Saving the Mother of Brazil | 64

Indigenous peoples were also granted participation in the groups of formulation, evaluation, and monitoring of health policies from the local to the national levels (Presidencia da República: Casa Civil, 1999) ${ }^{6}$. Both territory and health rights are not only intertwined as markers of indigenous differential treatment, but also in the fight against COVID-19.

In what concerns indigenous health, their demands for governmental action amid the pandemic have prioritized two fronts: immediate access to health assistance in accordance with their cultures and traditions; and the end of the invasion of their territories by unauthorized individuals and private enterprises (Emergência Indigena, 2020). This is because these individuals not only work as potential vectors of the disease, but also destroy the environment and violate indigenous cultural and spiritual relationships with it (Maracá, 2020, 3:20). This article thus focuses on these two sources of conflict through national and some regional initiatives undertaken to curtail the threats that COVID-19 has posed to their communities, especially considering that from the approximately 818,000 indigenous peoples in the country, more than 30,000 had already contracted the virus by September 2020 (Fellet, 2020b).

\section{Demanding the Fulfillment of Rights, Pushing for Greater Political Participation}

As SARS-Cov-19 reached indigenous territories, the Articulation of Indigenous Peoples of Brazil's (APIB) detailed mobilization front against the pandemic represents their national grassroots campaigning to shape the processes and decisions towards state health assistance (Emergência Indígena, 2020). Created in 2005, APIB has been the national center for regional indigenous organizations. It has sought to strengthen both the unity among different native peoples throughout Brazil, and strategies for mobilization against violence and threats to indigenous rights $(A P I B, 2020)^{7}$. Because of the pandemic in 2020, APIB

\footnotetext{
${ }^{6}$ The "global trend" regarding indigenous rights stemmed from the rise of social movements activism in the 1980s in which indigenous peoples worldwide pursued international relations and alliances to empower their communities locally. It occurred because such movements were not strong domestically. For more see Alison Brysk (1996).

${ }^{7}$ APIB is currently represented in all Brazilian states through seven regional organizations. For more, see "Quem Somos," APIB Oficial.
} 
launched the "Indigenous Emergency" campaign, which has demonstrated that the indigenous immediate problems with both exposure to COVID-19 and adequate health services reflect greater challenges to the fulfillment of their citizenship rights and their pursuit of self-determination (APIB, 2020a). These include adequate provision of health services, and constitutional rights to their homeland - which have been constantly violated by clandestine mining and logging groups inside their territories (Fellet, 2020b). In seeking national and international support, indigenous peoples have created spaces for popular political participation that seek to pressure the state into complying with its responsibilities.

The "Indigenous Emergency" campaign has served the broader purpose of taking action against the growing lack of state accountability toward indigenous rights. The campaign homepage, also available in English and Spanish, declares it "proposes general strategies for the elaboration of regional and local plans of action" in a collaborative manner among civil society, indigenous and nonindigenous partnering organizations against the pandemic (APIB, 2020h). Their "Plan to Stand Against COVID-19" is divided into three axes: comprehensive and differential healthcare to control the spread of Covid-19, legal and political actions, and health communication and information (APIB, 2020f). All the planned axes seek to curtail the constant violation of indigenous rights- which has complicated their already vulnerable condition to the pandemic (Recomendação no. 11/2020, 2020).

To ascertain the commitment of indigenous peoples to directly intervene in official health policies, the campaign has promoted indigenous narrative about COVID-19 prevention and control among their communities. It has done so by establishing protocols of action that both indigenous organizations and the state should implement together to prevent catastrophic consequences to native lives (APIB, 2020f). Indeed, due to their advocacy, the Federal Public Ministry released a Recommendation (n. 11/2020 MPF) in 2020 acknowledging the greater vulnerability of indigenous peoples to respiratory diseases, and requesting local active protection of their health and their rights by local, regional and national governance to prevent the risk of genocide (Recomendação no. 11/2020, 2020). APIB's plan against COVID-19 not only corroborated the ministerial recommendation but also emphasized the importance of indigenous presence in 
Saving the Mother of Brazil | 66

governmental decisions "on a permanent and continuous basis" so that the state can act in accordance with the cultural particularities of their communities ( $A P I B$, 2020f). The campaign also details the duties of APIB during the pandemic. These include, for instance, supporting the purchase of personal protective equipment to health teams in indigenous communities; working with international organizations, such as the UN and the Inter-American System, to strengthen the defense of human rights of indigenous peoples; and developing educational content regarding the indigenous reality amid the pandemic to foster solidarity to their cause $(A P I B, 2020 \mathrm{f})$. The development of this $\mathrm{R} \$ 100 \mathrm{mi}$ plan in itself demonstrates how indigenous peoples have sought to shape the terms of debates and decisions about indigenous healthcare under the state (APIB, 2020f). Consequently, their commitment to active citizenship seeks to increase governmental accountability over constitutional violations of their citizenship rights that have been exacerbating health risks among their populations.

\section{Demanding Guaranteed Rights to Health}

Protecting their rights means seeking their own methods of data collection about COVID-19 in their communities while dealing with challenges of an underfunded public health system. The immediate challenges the pandemic has caused among indigenous peoples involve the difficulties in access to accurate data on COVID-19's impact in native individuals both within and without indigenous lands, and the inaction of the government in promoting effective strategies of prevention and health assistance $(A P I B, 2020 \mathrm{e})$. This is a reflection of budgetary cuts that have taken place in multiple federal agencies responsible for indigenous rights. They comprise a 37\% cut for 2020 demarcation and land protection programs from the National Foundation of Indigenous Peoples (Funai) and a 16\% deduction on funds in 2019 for the Special Office for Indigenous Health (Sesai) (Fundação Nacional do Índio, 2020a; Leitão, 2019). Funai is the indigenist office of the Brazilian state in charge of identifying, delimiting, demarcating, and regularizing the registration of lands traditionally occupied by indigenous peoples, critical responsibilities not only for the maintenance of indigenous rights but also, as will be discussed later, for the prevention of COVID19 (Fundação Nacional do Índio, n.d.a). Attempting to alleviate the consequences of decreased investments and their social impact during the pandemic, APIB and 
regional organizations have defended "the relevance and validation of mechanisms of community-based and participatory monitoring on the spread of COVID-19 in [our] territories (APIB, 2020e)."

Problems with arbitrary and flawed classificatory methods about indigenous victims of COVID-19 in official data have led indigenous organizations to implement alternative strategies for gathering information on their own, which has served to promote their demands for self-determination and for the improvement of health services. According to different regional indigenous organizations, the Special Office for Indigenous Health (Sesai) has fallen short on its monitoring of indigenous individuals contaminated with COVID-19 (APIB, 2020e). For instance, it became clear for the Coordination of Indigenous Organizations of the Brazilian Amazon (Coiab) that Sesai "was not promoting assistance, neither keeping records of indigenous people who live in urban centers or in lands that are yet to be ratified", namely, lands that need to have their geographical boundaries set with approval from a presidential decree (Fundação Nacional do Índio, n.d.b). Because of these flaws, APIB has disclosed that each affiliated regional organization has developed their own method of data collection, such as the development of apps for registration of cases, which is critical for the elaboration of emergency strategies that serve indigenous populations $(A P I B, 2020 \mathrm{e})$. Further, governmental indigenous organizations have been accused of institutional racism in situations in which native individuals were classified as pardos (mixed- race) when they sought public healthcare in urban spaces $(A P I B, 2020 \mathrm{e})$. This reality raises questions about the dynamics of identity politics and the impact of the state in social groups as it delimits social categories while conveying visibility through its delimitation for individuals to claim particular rights (Arruti, 1997).

Misclassifying indigenous individuals by other racial categories however contributes with inaccuracies in identification, which can promote erasures that affect their guaranteed rights and enforce historical exclusion(Farias, 2020; APIB, 2020e). This is particularly serious considering that indigenous peoples are supposed to receive differentiated health treatment (Presidencia da República, 1999; APIB, 2020e). In May, 2020, a project of law was created to make mandatory the use of ethnic-racial classifications from the national institute of statistics (IBGE) on the data of COVID-19 victims to improve the accuracy of 
Saving the Mother of Brazil | 68

information about the vulnerability of particular groups to the pandemic (Camara dos Deputados, 2020) ${ }^{8}$. To guarantee accuracy, indigenous peoples continue to track cases among themselves. According to their estimates, in March 2021, over 50,000 indigenous individuals had contracted COVID-19 within 163 peoples (APIB, 2020a).

Indigenous peoples' pinpointing of exact areas in need of investment against COVID-19 represent both their struggle to see hard earned health rights fulfilled, and their commitment to the expansion of their voices in governmental decisions. First, in noticing governmental shortcomings they demonstrate their awareness of state health obligations, such as Sesai's goal "to develop projects toward the integral attention to indigenous health and health education (...) while observing traditional indigenous practices (Ministério da Saúde, 2017)." The creation of Sesai in 2010 was a victory from indigenous advocacy towards a national implementation of health services that respect "the cultural specificities and the epidemiological profile of each people (Ministério da Saúde, 2017)." Yet, during the current presidency, Sesai suffered threats of dissolution. In 2019, the then minister of health, Luiz Henrique Mandetta, proposed a project that would turn Sesai (a national office) into a responsibility of individual states and municipalities, meaning that it would become dependent upon the already strained budget of local governments (Guimarães, 2013; Ramos, 2020). After thousands of indigenous people went to the streets of the country to protest, Mandetta decided to maintain Sesai, which is responsible for 765,000 people from 305 ethnicities (Diario do Nordeste, 2019). Amid COVID-19, APIB has taken stock of the immediate problems that are currently violating their health rights, which include challenges with access to fresh water necessary for hygiene; lack of fluvial, air and land transportation for urgent cases, and the risk indigenous peoples have been exposed to when going to urban centers to receive the federal government relief fund $(A P I B, 2020 \mathrm{~g})$. Concurrently, they have filed lawsuits that seek governmental compliance with established healthcare protocols, such as the need for sanitary barriers, to protect indigenous peoples from contamination (Ministério Público Federal, 2020).

\footnotetext{
${ }^{8}$ The official classifications from IBGE are white, black, pardo, indigenous and yellow. For more information, see Câmara dos Deputados (2020).
} 
Bringing attention to necessary protocols in health assistance also demonstrate their push for greater participation in healthcare decisions. Their plan to combat COVID-19 addresses the need for governmental enforcement of sanitary protocols among health providers when in contact with indigenous peoples, and adequate assistance to native individuals under the state-based indigenous health services $(A P I B, 2020 \mathrm{~g})$. These concerns were founded in the absence of well-structured state plans of action which, in an interview given to the French radio station RFI, APIB leader Kretã Kaingang claimed to come from a lack of commitment from the Brazilian state with indigenous peoples (Capuchinho, 2020). President Bolsonaro's vetoing of twenty-two critical paragraphs from the project of law (PL) no. 1142/2020 on the protections of indigenous health during the pandemic provided a strong example of Kaingang's concerns (Presidencia da República, 2020). Even though the PL was eventually approved (after lawmakers, members of the federal human rights commission and the UN representative to Brazil acted upon the matter) some of the vetoed items were fundamental for their compliance with WHO sanitary guidelines ( $W H O$, 2020). These encompassed, for instance, "universal access to potable water" and "distribution with no charge of hygienic, cleaning and disinfection materials to villages or indigenous communities officially ratified or not, including in urban centers (Presidência da República, 2020)." Because of the slow responses in governmental action during the COVID-19 crisis, regional organizations have sought solidarity to address some of the most pressing issues within their communities.

The absence of greater action from governmental agencies to protect indigenous health has unjustly pressured varied organizations to enact their own plans of control and prevention towards COVID-19. For instance, health initiatives from Coiab, and the Articulation of Indigenous Peoples and Organizations from the Northeast, Minas Gerais and Espírito Santo (APOINME) originated from the "inexpressive [healthcare] contributions from governmental institutions, such as Funai and Sesai, whose missions involve the implementation of our rights (APOINME, 2020)." Considered one of the main mediators between the indigenous populations in the northern states and the federal government, Coiab's emergency plan has prioritized improved communication among the 
communities it represents ${ }^{9}$, administration of emergency and primary care, provision of food, and promotion of indigenous healing. To increase access to information about the coronavirus, Coiab has also partnered with national and international groups to create educational podcasts, pamphlets and posters in indigenous languages focusing on preventive measures against COVID-19 $(C O I A B, 2020)^{10}$. Further, it has invested in the purchase and distribution of oxygen tanks, generators, masks, food and medication. Their efforts have contributed with other initiatives to support about eighty thousand indigenous individuals from thirty different peoples by September 2020 (APIB, 2020e). Similarly, Apoinme has established its own partnerships with universities, social movements, indigenous and non-indigenous organizations to monitor the spread of COVID-19, develop sanitary barriers and provide subsistence to indigenous in need $(A P I B, 2020 \mathrm{e})^{11}$. About forty-thousand individuals have received food support from Apoinme, whereas those responsible for the monitoring of sanitary barriers were given face shields, thermometers and oximeters (APIB, 2020e). Notwithstanding all of these immediate health assistance efforts, ultimately COVID-19 prevention and control are intrinsically dependent upon the maintenance of their territorial rights.

\section{“The Territory is Sacred" " COVID-19 in Indigenous Lands}

Fighting against COVID-19 has been directly associated with native claims to sovereignty over their territories. In particular, the invasion of indigenous lands has caused threats to both the environment and their health. Peoples who live voluntarily isolated, such as the Pirititis in the northern state of Roraima, for instance, have faced increased health threats to the growing presence of clandestine miners near their land and their population of one-hundred

\footnotetext{
${ }^{9}$ Coiab oversees native peoples in the states of Acre, Amapá, Amazonas, Maranhão, Mato Grosso, Pará, Rondônia and Tocantins. For more see, Emergência Indígena, 51.

${ }_{10}$ Partners include the Federal University of Roraima's Insikiran Institute, which focuses on the education and professionalization of indigenous peoples in Roraima through a multicultural perspective; Roraima's Indigenous Council (CIR) and the US-based non-profit Nia Tero. For more, see COIAB (2020).

${ }^{11}$ Apoinme represents the states of Alagoas, Bahia, Ceará, Espírito Santo, Minas Gerais, Paraíba, Pernambuco, Piauí, Rio Grande do Norte and Sergipe.

12 “Ancestralidade,” Maracá Documentary, video, 3:20.
} 
individuals ( $A P I B, 2020 \mathrm{e})$. Meanwhile, in the southeastern region of the state of Pará, the invasion of demarcated indigenous land by clandestine miners, loggers and land grabbers have exponentially affected the rise of COVID-19 infection among the Karipuna, Yanomami and Kayapó peoples ( Desmatamento e Covid19 explodem em Terras Indígenas Mais Invadidas da Amazônia, 2020). The sanitary districts responsible for these populations have registered, respectively, an infection growth of $355 \%, 215 \%$ and $138 \%$ by the coronavirus among them between July 7 and August 29, 2020 (Instituto Socioambiental, 2020).

In taking legal and social measures to deal with the threats these invasions have caused to their lives, indigenous peoples have created opportunities for political attention to their demands as they pressured the Brazilian state to take measures against these violations to their rights. For example, to demand protection during the pandemic and governmental action against illegal loggers and miners, the Kayapós blocked a key Brazilian grain road in August, 2020 in the state of Pará (Landau, 2020). Concurrently, APIB filed a lawsuit through the Brazilian supreme court to demand the federal government to adopt an emergency plan of COVID-19 control in indigenous territories (Vilarino, 2020). An injunction was also requested and received the support of six political parties for the implementation of immediate measures of protection, including the creation of sanitary barriers and the removal of clandestine individuals from indigenous territories. APIB also published the "Complicity in Destruction" report to seek national and international support for their territorial entitlements in October 2020 (APIB, 2020a).

The combating against COVID-19 has led indigenous populations to find and report direct sources of illicit land exploitation in the Amazon basin to increase visibility of the parts involved and thereby strengthen the possibilities for accountability of their actions. Along with the Amazon Watch (a transnational nonprofit organization headquartered in the United States that aims to protect the rainforest and indigenous rights) APIB has utilized the "Complicity in Destruction" 13 report to present to "the great actors of the global market"

\footnotetext{
13 "Complicity in Destruction" was based on studies realized by Profundo, a non-profit Dutch institution which focuses on sustainability and social justice, and De Olho nos Ruralistas, a news outlet whose mission involves following the agribusiness decisions and its consequences in Brazil. For more, see APIB (2020a).
} 
Saving the Mother of Brazil | 72

information about how their investments are contributing to "the destruction of the largest tropical forest on the planet" ( $O$ Financiamento da Destruição, 2020; The Amazon: A Global Treasure, n.d.). Based on studies conducted by non-profit organizations in Brazil and Holland, the report claims that three sectors of private investments have caused most conflicts with indigenous peoples: agrobusiness, electricity, and mining $(A P I B, 2020 \mathrm{a})$. Besides the risk of contamination by COVID-19, issues with clandestine exploitation of native lands include deforestation, pollution of rivers that are critically important as both food and water resources for native populations, and the threat of relocation based on the potential infeasibility of living in environmentally exhausted territories ( $A P I B$, 2020a). Brazilian companies that indigenous groups have accused of contributing to these problems include Vale, the second largest producer of iron ore and nickel in the world; JBS, the largest producer of beef in the world; and Cosan/Raizen, specialized in sugarcane and ethanol productions. Private investments in the Amazon basin often come from international banks and corporations from places including the United States, France, Germany, China and Japan (APIB, 2020a). The exploitation of indigenous lands has greatly increased since 2019, a consequence of the current neoliberal government of president Jair Bolsonaro who believes that "idle" native reserves jeopardize the country's economic development (Verdélio, 2019). The growth of mining and the agribusiness activities have provoked problems, especially during the pandemic.

In exposing mining companies and investors' potential fault over the contamination of indigenous peoples to COVID-19, they attempt to curtail illicit mining activities in the Amazon basin and pressure the Brazilian government to guarantee indigenous sovereignty over their territories. A study developed by the Federal University of Minas Gerais and the Socio-Environmental Institute (ISA) has classified the Yanomamis as the most vulnerable group in the country to the pandemic due to the presence of clandestine miners in their land (Fellet, 2020a). Located near the Brazilian frontier with Venezuela and crossing the states of Amazonas and Roraima, the Yanomami population could be reduced by almost $7 \%$ because of the presence of about 20,000 miners in their lands (Fellet, 2020a). According to the Oswaldo Cruz Foundation (Fiocruz), the nearly 27,400 Yanomami and Ye'kwana inhabitants of the Yanomami land (about the size of Portugal) are running the risk of genocide "with complicity of the Brazilian state" if it does not expel those miners from their lands and improve medical assistance 
to their 334 villages (Fellet, 2020a). Even though the area received demarcation in 1992, miners' activities have remained because of gold reserves.

Through a similar attempt to call national and international attention over the impact of the agribusiness in the spread of COVID-19, indigenous peoples have sought to shape public policy to benefit their rights. For example, in June 2020, indigenous employees in slaughterhouses and meat packing plants located near indigenous villages were infected by COVID-19 while working in the Southern and Mid-Western regions of Brazil (APIB, 2020e). Similar circumstances led to the transmission of the coronavirus to individuals in the Indigenous Reservation of Dourados in Mato Grosso do Sul as indigenous employees of slaughterhouses contracted the disease at work and became vectors to communities such as the Oco'y in Paraná and the Xapecó in Santa Catarina. From the 850 inhabitants of the Oco'y village, eighty-eight were contaminated and their shaman succumbed to it (Kateivas, 2020; Foscaches and Klein, 2020). Such events led APIB to reinforce the status of vulnerability of indigenous individuals with the Public Ministry of Labor (MPT) and the Public Federal Ministry (MPF) so that indigenous laborers could be exempted from work without compromising their salaries $(A P I B, 2020 \mathrm{e})$. COVID-19 threats near their lands have thus become a critical part of indigenous struggles to enforce their territorial rights.

The threats the pandemic has caused among indigenous populations have made them seek alliances, legal and social strategies to have their demarcation rights fulfilled. Even though the constitution of 1988 had stipulated the demarcation of all indigenous land by the year 1993, so far, from 1,290 indigenous lands in Brazil only 408 have been demarcated (APIB, 2020e). 287 of them are under the process of demarcation, and other sixty-seven have other terminologies based on how they were acquired (for instance, if by a third-party donation or dispossession by the federal government) (APIB, , 2020d; Fundação Nacional do Índio, n.d.a.). Meanwhile, 528 territories have received no official recognition despite the claims of the native peoples who inhabit them $(A P I B, 2020 \mathrm{e})$. The demarcation process has become even slower during the past two presidencies. Whereas former president Michel Temer ratified only one indigenous land during his two-and-a-half year term, president Bolsonaro has explicitly said that "as long as I am the president there will be no demarcation of indigenous land" (Verdélio, 
Saving the Mother of Brazil | 74

2019). The deliberate dismissal of constitutional rights represents a neoliberal agenda that only reinforces the importance of active citizenship for their maintenance. Concurrently, indigenous peoples continue their battles through court, through the internet and through the networks of support they have forged or seek to forge with other minority groups and the rest of the Brazilian citizenry (Revista Novo Tempo, 2020; APIB, 2020d).

\section{Conclusion}

Brazilian experience with the pandemic resembles challenges aboriginal and indigenous communities have been facing throughout the world. For example, the Waorani in Ecuador, the Navajo in the United States, or the Congress of Aboriginal People of Canada, have also taken measures to claim their rights against discriminatory and/or neglected indigenous health measures in their countries amid COVID-19 (Godin, 2020; Cardona, 2020). The extensive measures indigenous peoples in Brazil had to go through to find alternative solutions against COVID-19 though raise important reflections about not only the neoliberal challenges they are having to face under the current presidency, but also their praxis of active citizenship for the maintenance and fulfilment of their guaranteed rights. Notwithstanding the power imbalances between them and the federal government, in demanding the acknowledgment of health and territorial entitlements they have pushed back on growing attempts of weakening spaces for civic involvement; have exposed governmental shortcomings in health assistance; and have secured some victories in the acknowledgment of their rights, including support from the supreme court to include them as a priority for vaccination (Miotto, 2021). In trying to directly shape decisions in official healthcare and to protect their territories, indigenous peoples have displayed critical exercises of rights claiming which strengthen and shape Brazilian democratic experiences with civic participation and contestation for the improvement of state decisions.

\section{References}

Amazon Watch (n.d.). The Amazon: A Global Treasure. Available at: https://amazonwatch.org/about (Accessed: August, 2020). 
APIB. (2020a) Cumplicidade na Destruição III: Como Corporações Globais Contribuem para Violações de Direitos dos Povos Indígenas da Amazônia Brasileira. Available at: https://amazonwatch.org/assets/files/2020cumplicidade-na-destruicao-3.pdf (Accessed January, 2021).

APIB. (2020b) Emergência Indigena. Available at: https://apiboficial.org/emergenciaindigena/ (Accessed August, 2020).

APIB. (2020c) Maracá: A Mãe do Brasil é Indígena. (2020) [Video]. http://emergenciaindigena.apib.info/maraca/ (Accessed August, 2020).

APIB. (2020d) Maracá: Ancestralidade. (2020) [Video]. https://emergenciaindigena.apiboficial.org/maraca/ (Accessed August, 2020).

APIB. (2020e) Nossa Luta é pela Vida: COVID-19 e os Povos Indígenas; o Enfrentamento das Violências Durante a Pandemia [Online], pp. 1-106. Available at:

https://emergenciaindigena.apiboficial.org/files/2020/12/APIB_nossalutaepelavi da_v7PT.pdf (Accessed: August, 2020).

APIB. (2020f) Plan to Stand Against Covid-19(EN), pp. 29-43. Available at: https://emergenciaindigena.apiboficial.org/ (Accessed August, 2020).

APIB. (2020g) Plano de Enfrentamento da COVID-19 no Brasil, pp. 21, 31. Available at: <https://emergenciaindigena.apiboficial.org/>(Accessed August, 2020).

APIB. (N.d) Quem Somos. Available at: <https://apiboficial.org/sobre/> (Accessed July, 2020).

APIB. (2020h) Sobre [Online]. Emergência Indígena. Available at: $<$ https://emergenciaindigena.apiboficial.org/sobre/> (Accessed July, 2020).

APOINME. (2020) Plano Emergencial: Promoção e Defesa da Vida e Saúde dos Povos e Territórios Indígenas no Nordeste, Minas Gerais e Espírito Santo. [Online], p. 8. Available at: <https://a958dd00-53ab-439c-adca8b8594cf8bde.filesusr.com/ugd/2f57f4_128881d6c69f45f7bacd95c28cb56313.p df $>$ (Accessed January, 2021).

Arruti, J. (1997) A Emergência dos Remanescentes: Notas Para o Diálogo Entre Indígenas e Quilombolas. Mana 3(2), pp. 7-38 [Online]. Available at: 
Saving the Mother of Brazil | 76

$<$ https://www.scielo.br/scielo.php?script=sci_arttext\&pid=S010493131997000200001> (Accessed: January, 2021).

Bodley, J. (2014) Victims of Progress, $6^{\text {th }}$ ed., Lanham: Rowman and Littlefield Publishers.

Borges, A. (2020) Fragilizada Diante do Coronavírus, Saúde Indígena Teve Corte de $16 \%$ no Ano Passado [Online]. Estadão. Available at: $<$ https://saude.estadao.com.br/noticias/geral,fragilizada-diante-do-coronavirussaude-indigena-teve-corte-de-16-no-ano-passado,70003286346> (Accessed August, 2020).

Brysk, A. (1996) Turning Weakness into Strength: The Internationalization of Indian Rights. Latin American Perspectives 23(2), pp. 38-57.

Câmara dos Deputados (2020) Projeto Determina Inclusão da Cor nos Dados de Pessoa Contaminada por Covid-19 [Online]. Available at: $<$ https://www.camara.leg.br/noticias/662974-projeto-determina-inclusao-da-cornos-dados-de-pessoa-contaminada-por-covid-19/> (Accessed January, 2021).

Capitulo V- Do Subsistema de Atenção à Saúde Indígena (Presidência da República: Casa Civil) (1999). Available at: $<\mathrm{http}$ ://www.planalto.gov.br/ccivil_03/leis/19836.htm>.

Capuchinho, C. (2020) Estado Não Tem Compromisso com Povos Indígenas, Denuncia Cacique Kretã Kaingang em Meio à Pandemia. [Online] RFI. Available at: $\quad<$ https://www.rfi.fr/br/brasil/20200908-estado-n\%C3\%A3o-temcompromisso-com-povos-ind $\% \mathrm{C} 3 \% \mathrm{ADgenas}$-denuncia-cacique-kret $\% \mathrm{C} 3 \% \mathrm{~A} 3-$ kaingang-em-meio-\%C3\%A0-pandemia $>$.

Cardona, A. (2020) Ecuador: COVID-19 Llega a los Indígenas Waorani Mientras que Otros Pueblos Enfrentan Nuevos Problemas. [Online] Mongabay LATAM. Available at: <https://es.mongabay.com/2020/05/covid19-indigenas-ecuadorwaorani-kichwa-cofan/>.

Carvalho, I., Westphal, M. and Lima, V. (2007) Health Promotion in Brazil. Promotion \& Education 1, pp. 7-12.

Chalhoub, S. (1996) Cidade Febril: Cortiços e Epidemias na Corte Imperial. Rio de Janeiro: Companhia das Letras, pp. 61-87. 
COIAB. (2020) Plano de Ação Emergencial de Combate ao Avanço do Coronavírus e de Tratamento Entre os Povos Indígenas da Amazônia Brasileira [Online]. Available at: $<$ https://coiab.org.br/covid $>$.

Cueto, M. and Palmer, S. (2015) Medicine and Public Health in Latin America: A History. New York: Cambridge University Press.

Diario do Nordeste. (2019) Após Protestos, Ministro da Saúde Desiste de Extinguir Secretaria de Saúde Indígena [Online]. Available at: $<$ https://diariodonordeste.verdesmares.com.br/404?notfound=/politica/aposprotestos-ministro-da-saude-desiste-de-extinguir-secretaria-de-saude-indigena$1>$.

Farias, E. (2020) Coronavírus: Indígenas que Vivem na Cidade são Classificados como 'Brancos' no Amazonas [Online]. Amazônia Real. Available at: $<$ https://amazoniareal.com.br/coronavirus-indigenas-que-vivem-na-cidade-saoclassificados-como-brancos-no-amazonas> (Accessed August, 2020).

Fellet, J. (2020a) Covid-19 Ameaça Aldeias Yanomamis Vizinhas a Garimpo [Online]. BBC News Brasil em São Paulo. Available at: https://www.bbc.com/portuguese/brasil-52886924 (Accessed: August, 2020).

Fellet, J. (2020b) Em Meio à COVID-19, Garimpo Avança e se Aproxima de Índios Isolados em Roraima. [online], BBC News em São Paulo. Available at: https:/www.bbc.com/portuguese/brasil-52225713 (Accessed: August, 2020).

Foscaches, N. and Klein, T. (2020) Dos Frigoríficos às Plantações de Cana: Como o Agronegócio Expôs Indígenas à COVID-19. [online], Repórter Brasil. Available at: <https://reporterbrasil.org.br/2020/06/dos-frigorificos-asplantacoes-de-cana-como-o-agronegocio-expos-indigenas-a-covid19/>(Accessed: August, 2020).

Fundação Nacional do Índio. (n.d.a) Terras Indígenas: o Que é? [Online]. Available at: <http://www.funai.gov.br/index.php/nossas-acoes/demarcacao-deterras-indigenas $>$.

Fundação Nacional do Índio. (n.d.b) A Funai [Online]. Available at: $<$ https://www.gov.br/funai/pt-br/acesso-a-informacao/Institucional $>$. 
Saving the Mother of Brazil $\mid 78$

Fundação Nacional do Índio. (n.d.c) Modalidades de Terras Indígenas [Online]. Available at: <http://www.funai.gov.br/index.php/indios-no-brasil/terrasindigenas $>$.

Gibson, C. (2019) Movement-Driven Development: The Politics of Health and Democracy in Brazil. Stanford: Stanford University Press, pp. 1-27.

Godin, M. (2020)'We Know What is Best for Us': Indigenous Groups Around the World Are Taking COVID-19 Responses Into Their Own Hands. [Online]. Time. Available at: $<$ https://time.com/5808257/indigenous-communities-coronavirusimpact/>.

Guimarães, C. (2013) Desafios da Gestão Municipal do SUS. Escola Politécnica de Saúde Joaquim Venâncio [Online]. Available at: $<$ https://www.epsjv.fiocruz.br/noticias/reportagem/desafios-da-gestaomunicipal-do-sus>.

Hale, C. (2004) Rethinking Indigenous Politics in the Era of the 'Indio Permitido.' NACLA Report on the Americas 38(2), pp. 1-7.

Hochman, G. (2011) Vacinação, Varíola e uma Cultura de Imunização no Brasil. Ciência e Saúde Coletiva, [online] 16(2), pp. 375-386.

Holder, C. and Corntassel, J. (2002) Indigenous Peoples and Multicultural Citizenship: Bridging Collective and Individual Rights. Human Rights Quarterly (24), pp. 126-51.

Instituto Socioambiental. (2020) Desmatamento e Covid-19 explodem em Terras Indígenas Mais Invadidas da Amazônia. [Online]. Available at: $<$ https://www.socioambiental.org/pt-br/noticias-socioambientais/desmatamentoe-covid-19-explodem-em-terras-indigenas-mais-invadidas-da-amazonia> .

Kateivas, Mari. (2021) Indígenas Voltam a Trabalhar em Frigorífico Após Controle da Covid-19 em Aldeia de São Miguel do Iguaçu [Online]. G1. Available at: $\quad<$ https://g1.globo.com/pr/oeste-sudoeste/noticia/2021/01/07/indigenasvoltam-a-trabalhar-em-frigorifico-apos-controle-da-covid-19-em-aldeia-de-saomiguel-do-iguacu.ghtml $>$. 
Krexu, M. (2020) A Mãe do Brasil é Indígena. [Online]. Xapuri Socioambiental. Accessed August, 2020. <https://www.xapuri.info/sagrado-indigena/a-mae-dobrasil-e-indigena/.

Landau, L. (2020) Indigenous Protest Over COVID-19 Continues on Brazilian Grain Highway. Reuters [Online]. Available at: $<$ https://www.reuters.com/article/us-health-coronavirus-brazilindigenous/indigenous-protest-over-covid-19-continues-on-brazilian-grainhighway-idUSKCN25E23J>.

Leitão, M. (2019) Corte no Orçamento da Funai Pode Inviabilizar Ações de Proteção a Índios, Dizem Servidores. [Online]. G1. Available at: $\quad<$ https://g1.globo.com/politica/blog/matheus-leitao/post/2019/10/24/corteno-orcamento-da-funai-pode-inviabilizar-acoes-de-protecao-a-indios-dizemservidores.ghtml>.

Lima, V. (2019) Participatory Citizenship and Crisis in Contemporary Brazil. Dublin: Palgrave Macmillan.

Million, Dian. (2013) Therapeutic Nations: Healing in an Age of Indigenous Human Rights. Tucson: The University of Arizona Press.

Miotto, T. (2021) STF Suspende Resolução da Funai que Restringia Autodeclaração Indígena. [online] CIMI. Available at: $<$ https://cimi.org.br/2021/03/stf-suspende-resolucao-funai-restringiaautodeclaracao-indigena/ $>$.

Ministério da Saúde. (2017) Sobre a Área [Online]. Available at: $<$ https://antigo.saude.gov.br/noticias/676-assuntos/saude-indigena/41324-sobrea-area>.

Ministério Público Federal. (2020) Arguição de Descumprimento de Preceito Fundamental N.709 [Online]. Available at: https://politica.estadao.com.br/blogs/fausto-macedo/wpcontent/uploads/sites/41/2020/12/peca-667-adpf-709_071220204908.pdf (Accessed January, 2021).

Miraftab F. and Wills, S. (2005) Insurgency and Spaces of Active Citizenship: The Story of Western Cape Anti-Eviction Campaign in South Africa. Journal of Planning Education and Research 25, pp. 200-217. 
Saving the Mother of Brazil | 80

Presidência da República. (2020) Diário Oficial da União [Online]. Available at: $<$ https://pesquisa.in.gov.br/imprensa/jsp/visualiza/index.jsp?jornal=515\&pagina $=6 \&$ data $=08 / 07 / 2020>$.

Ramos, A. (2020) Com Investimento Federal Insuficiente, Saúde Será um dos Principais Desafios para os Próximos Prefeitos. [Online]. Yahoo Notícias. Available at: $<$ https://br.noticias.yahoo.com/com-investimento-federalinsuficiente-saude-sera-um-dos-principais-desafios-proximos-prefeitos143048980.html>.

Recomendação no. 11/2020, Ministério Público Federal (2020) [Online]. Available at: $\quad<$ http://www.mpf.mp.br/df/sala-deimprensa/docs/RecomendacaoSaudeIndigenaCOVID19.pdf $>$.

Revista Novo Tempo. (2020) Indígenas e Quilombolas se Unem Contra o Coronavirus [Video]. Available at: $<\mathrm{https} / / \mathrm{www} . y o u t u b e \cdot c o m / w a t c h ? \mathrm{v}=\mathrm{A}-$ OZ7g4HqJM>.

Sartori Jr., D. and Leivas, P. (2017) O Direito à Saúde dos Povos Indígenas e o Paradigma do Reconhecimento. Direito e Práxis 8(1), pp. 86-117 [Online]. Available at: https://www.scielo.br/scielo.php?script=sci_arttext\&pid=S217989662017000100086 (Accessed: January, 2021).

Senado Federal. (1988) Artigo 231 [Online]. Available at: $<$ https://www.senado.leg.br/atividade/const/con1988/con1988_08.09.2016/art_2 31_.asp>

Souza, F. and Souza, M. (2020) O Direito de Participação Ativa e a Elaboração de Políticas Públicas de Contenção da COVID-19 nas Populações Indígenas. Vukápavano: Revista Terena (3), pp. 183-200.

Sowell, D. (2015) Medicine on the Periphery: Public Health in Yucatán, Mexico, 1870-1960. Lanham: Lexington Books.

Verdélio, A. (2019) Bolsonaro Diz que Não Fará Demarcação de Terras Indígenas. Agência Brasil [Online]. Available at: $<$ https://agenciabrasil.ebc.com.br/politica/noticia/2019-08/bolsonaro-diz-quenao-fara-demarcacao-de-terras-indigenas $>$. 
Vilarino, C. (2020) Indígenas Entram na Justiça para Obrigar o Governo Federal a Adotar Plano Contra COVID-19. [Online]. Globo Rural. Available at: $<$ https://revistagloborural.globo.com/Noticias/Sustentabilidade/noticia/2020/06/i ndigenas-entram-na-justica-para-obrigar-governo-federal-adotar-plano-contracovid-19.html>.

Weber, B. (2004) 'Fragmentos de um Mundo Oculto: Práticas de Cura no Sul do Brasil', in Hochman, G. and Armus, D. (ed) Cuidar, Controlar, Curar: Ensaios Históricos sobre Saúde e Doença na América Latina e Caribe. Rio de Janeiro: Editora Fiocruz, pp. 157-215.

World Health Organization. (2020) Coronavirus Disease (COVID-19) Advice for the Public. [Online]. Available at: $<$ https:/www.who.int/emergencies/diseases/novel-coronavirus-2019/advice-forpublic $>$.

Yashar, D. (2005) Contesting Citizenship in Latin America: The Rise of Indigenous Movements and the Postliberal Challenge. Cambridge: Cambridge University Press. 